\title{
A cidade "com qualidade" Estudo de memória e esquecimento sobre medo e crise na cidade de Porto Alegre
}

\author{
CORNELIA ECKERT
}

\begin{abstract}
Resumo: Trazemos aqui uma notícia etnográfica desenvolvida em pesquisa na cidade de Porto Alegre, no intuito de tratar do estudo da memória do cotidiano sob o enfoque da cultura do medo, em face das situações de crise e violência no mundo contemporâneo, integrando a perspectiva do resgate da pluralidade e diversidade de memórias coletivas e da preservação do patrimônio etnológico do mundo urbano segundo os diferentes sujeitos sociais, com vistas à elaboração de ações culturais nas modernas cidades industriais que contemplem os lugares da memória de seus habitantes.
\end{abstract}

Palavras-chave: cidade; memória; esquecimento; medo; crise.

\section{“As desqualidades" do homem moderno}

Sem ética, sem valores, nenhuma verdade, sem qualidades, self dilacerado. Esta é a descrição do principal personagem da obra do austríaco Robert Musil, em $O$ homem sem qualidades, publicado na década de 1930, uma das tantas obras que configuram a condição humana no mundo urbano moderno contemporâneo, mergulhada na incerteza da idéia de tempo e da trajetória da história social. Neste artigo, buscamos tratar da condição de crise do tempo social e cultural do mundo cotidiano no qual se movem os habitantes em contextos citadinos modernos, convergindo à preocupação levantada por autores como Alfred Schutz (1972) e Clifford Geertz (1978), que tratam do conhecimento da estrutura conceptual expressa nas formas simbólicas, descrevendo e analisando a estrutura significativa da experiência das pessoas, conforme ela é apreendida no mundo social em uma condição histórica e política específica

\footnotetext{
* Doutora em Antropologia Social, pela Paris V, Sorbonne (França) e professora no Departamento de Antropologia da UFRGS
}

(Geertz, 1978, p. 229). O mundo da vida cotidiana enfrentado na condição brasileira contemporânea confere ao citadino a experiência da desagregação das relações sociais em face da insegurança e da vulnerabilidade que ameaçam os projetos de construção de um tempo ético fundado na perspectiva de valores de reconhecimento e de responsabilidade, e que gera, nos termos de Paul Ricoeur (2000), a desconfiança na cultura e a descrença de uma continuidade social. Ricoeur refere-se aqui à ameaça do esquecimento dos símbolos significantes da qualificação humana, da intimidação de uma amnésia da experiência humana no passado.

Crimes contra as pessoas, crimes contra a propriedade, crimes de colarinho branco, fraudes, corrupção, delinqüência, tráfico, desemprego... as referências de performance criminais são complexas e antagônicas. No contexto atual, em face da definida violência urbana, as sociabilidades públicas e a vida privada conhecem sistematicamente novos constrangimentos pelo aumento da criminalidade, transformando nossas concepções culturais sobre a confiança. Dinamiza-se uma pluralidade de reações de proteção 
para garantir uma rotina que imprima liberdade de ir e vir. Estrutura-se uma avalanche de dispositivos maquinários os quais alimentam uma indústria que sofistica o mercado de segurança na aparente diminuição da vulnerabilidade, delineando conceitos culturais de medo e temor que implicam socialmente conflitos na vida pública e privada. Uma discursividade generalizante sobre a insegurança e os riscos divulgados predominantemente pela mídia atribui causas e consequiências da violência urbana, orientando o confronto do conflito para a atividade pública que, em contraste, encerra os citadinos em uma passividade como fórmula de autoproteção. Uma lógica discursiva que concebe erros de uma economia neoliberal e a necessária desconfiança do "outro", "estranho". A civilidade não tem mais uma forma progressiva constante e as disformidades de um cotidiano marcado pelas ameaças e pelo sentimento do medo associam a urbanidade e o hedonismo aos efeitos de uma crise mal aparada pelos vazios de sentido das ações democráticas.

No nível da ação do Estado e das instituições públicas, confundem-se debates políticos com posturas ideológicas, atos sociais com defesa da sociedade contra indivíduos ameaçadores, decisões éticas com regras morais como ideais valorativos de uma sociedade que não encontra a face da responsabilidade no espelhamento das violências e conflitos sociais.

As ciências humanas compreendem que está em questão a noção de subjetividade, da objetividade da liberdade, da legalidade do direito contra o "indivíduo" que ameaça o bem-estar de uma coletividade.

De um ato extremo por uma defesa social encontramos não raro o encaminhamento de instituições político-educacionais de perspectivas higienizadoras da mentalidade dita degradada. Em outra, a ciência divulga os pressupostos de uma sociedade de riscos vitimada pela complexa desigualdade social e irremediável divisão social do trabalho e do poder.

Nesse processo, a pesquisa antropológica apresenta a preocupação de desdramatizar as disposições morais dessa cultura do medo que propaga limites de sociabilidades, engodos do mercado de segurança, segregação espacial, discriminação e desconfiança do outro.
Problematiza-se, neste estudo, como campo de investigação, portanto, a matriz macro de explicações da violência e crises urbanas como processo resultante da decadência dos vínculos sociais e do enraizamento da vida coletiva, a partir de estudos etnográficos no e do mundo urbano. Em 1997, ao iniciarmos este estudo, orientamos o tema do medo da criminalidade como uma das prioridades em nossos questionamentos antropológicos junto aos habitantes no contexto urbano. Esta análise se soma aos diversos estudos que compõem o projeto Banco de Imagens e Efeitos Visuais ${ }^{1}$ apresentados em diferentes suportes como fotografia, vídeo, som e texto, compondo as interfaces interpretativas deste texto em www.estacaoportoalegre.ufrgs. br.

\section{O porto pouco seguro}

A motivação para tratar do tema das feições dos medos e das crises em Porto Alegre surgiu no retorno de uma estada para doutoramento no estrangeiro, no início dos anos 1990, quando emergia em Porto Alegre um discurso sobre insegurança e vulnerabilidade diante dos imponderáveis da rotina provocados pelo aumento da violência na cidade.

Capital do estado do Rio Grande do Sul, Porto Alegre, conforme os indicadores oficiais, tem uma população de 1.400 .000 habitantes, em uma área de $476,30 \mathrm{~km}^{2}$. Os índices apontam também que $91 \%$ da população acima de 10 anos é alfabetizada e que a taxa de homicídios é de 2,43 por 10.000 habitantes.

Nessa década, a paisagem arquitetônica de Porto Alegre transformou-se radicalmente em decorrência do medo da violência. Proliferaram grades, porteiros eletrônicos, guaritas, arames e cercas elétricas, circuitos de alarme internos e externos não só em bairros identificados como "enobrecidos", mas também em bairros populares, onde os moradores e pequenos comerciantes recorriam a grades e cercas para dificultar roubos e assaltos cada vez mais freqüentes.

1. Coordenado por Ana Luiza Carvalho da Rocha e por mim e do qual faz parte uma equipe de pesquisadores e bolsistas de iniciação científica. Recorrer ao portal citado para suas referências. 
As transformações no espaço urbano fizeram-se intensas pela presença de equipamentos de segurança alimentados por uma indústria de prevenção com altos rendimentos. A fobia à criminalidade, que modificava vertiginosamente a estética da arquitetura urbana na cidade, era elemento de nossa própria biografia pessoal como moradora da cidade. Em 1993, hospedei em minha residência uma turista alemã que, desde o primeiro dia, confessou estar chocada com a agressividade da estética "de segurança" em Porto Alegre, pela presença de grades nas portas e janelas ou de seguranças privados em guaritas postadas em frente às residências. Dizia ter dificuldade de permanecer em um apartamento com grades nas portas e janelas, as quais a faziam sentir-se aprisionada e sufocada por não conseguir compartilhar desse ethos do medo, uma vez que em sua cidade, Munique, e em sua casa, nem mesmo trancava a porta.

A possibilidade de ser ator ou coadjuvante numa experiência de assalto, de roubo, de agressão ou de um seqüestro relâmpago tende a ser condicionante social do habitante comum na cidade. Paliativos de toda ordem, como miríade de ações que revelam práticas sociais (De Certeau, 1994), levavam, cada vez mais, os habitantes a um exercício de prevenção constante, em todas as classes, em todos os grupos etários e gêneros sociais, configurando uma estrutura imposta por novas determinações sociais.

Constata-se um aumento do crime contra o patrimônio, informam dados oficiais. As performances criminais transformam-se segundo mudanças conjunturais, como mostra o quadro evolutivo da violência urbana na cidade divulgado pela imprensa porto-alegrense, no jornal Zero Hora (consulta no portal do jornal, março 2005).

1. Décadas de 10 e 20 - tumultos e destruição de bondes.

2. Décadas de 30 e 40 - assaltos começam a ganhar espaço.

3. Décadas de 50 e 60 - nascem as grades nos muros.

4. Década de 70 - tráfico incipiente e repressão política.

5. Década de 80 - explosão do crime organizado.
6. Década de 90 - crimes importados; guerras entre quadrilhas causam homicídios; disseminação do tráfico e corrupção nas corporações de segurança.

7. Anos 2000 - violência indiscriminada, o crime desafia autoridades.

8. Anos 2000 a 2002 - aumentam os seqüestros relâmpagos; ladrões atacam clientes e os forçam a retirar dinheiro de caixas eletrônicos.

9. Anos 2002 a 2004 - seqüestro de gerentes de bancos; assaltos a motoristas em locais de estacionamento e em semáforos; aumenta o número de assaltos seguidos de morte.

O latrocínio é o maior fator para a opção por mudanças de hábitos rotineiros e para a adesão à fortificação da casa com instrumentos de vigilância e segurança. O medo ao furto, mas, sobretudo, ao roubo, caracterizado pelo emprego da violência, é o álibi para mudanças de rotinas, para restrições de práticas de deslocamento "sem preocupações" e para buscas de fricções de isolamento com grades, muros e toda parafernália de prevenção ao crime .

Cada habitante toma em conta novos gestos, novos cuidados, ponderando ações, percursos e turnos. Tomam cuidado com os horários, sobretudo noturnos; fazem contratos de seguro para proteger seus carros, sua casa; contratam vigias residenciais ou cotizam segurança de bairro; instalam equipamentos de alarmes em residências; locomovem-se de táxi à noite ou evitam sair nesse horário; mudam-se para condomínios fechados ou apartamentos com vigilância 24 h etc.

\section{A insegurança de cada dia}

Nosso universo de estudo consiste em habitantes que se definem como pertencentes a camadas médias. Junto a eles, propus a condição de pesquisa por visitas em suas residências. As entrevistas tinham por eixo básico um roteiro sobre a trajetória familiar, a relação com a cidade em seu cotidiano e os relatos de situações biográficas de vitimização, quando conversamos sobre suas rotinas e ações em relação ao sentimento de medo e à vulnerabilidade do viver cotidiano. Partia da imagem genérica de a população do segmento médio brasileiro estar significativamente preocupada com a proteção de 
seu patrimônio em um contexto urbano fragilizado pelas desigualdades sociais e de ser essa camada a mais aclamada, pelos meios de comunicação de massa, como vítima da criminalidade urbana, pela perda de previsibilidade de suas experiências sociais cotidianas.

Trata-se de uma rede de habitantes do centro da cidade e de bairros residenciais, conformando um grupo com algumas características recorrentes, como o fato de ter residência própria, constituir famílias nucleares (com duas exceções no caso de filhas separadas que retornaram à casa dos pais para, junto aos avós, criarem o filho), ser branco e estar acima de 50 anos de idade (80\%).

Como próprio das narrativas, as contradições dos relatos eram ricas ao tratar da adesão ao novo padrão de segregação espacial e mercado de segurança e ao dimensionar formas de "invenção do cotidiano" (De Certeau, 1994), novas formas de sociabilidade (Simmel, 1934) e estilos de vida (Schutz, 1972 e Gilberto Velho, 1981).

Realizamos uma média de vinte entrevistas gravadas com câmeras digitais e transcritas, para fins de edição do documentário intitulado Cidade sitiada, lançado em 2001 (produção Biev/UFRGS). Os demais contatos foram episódicos, com entrevistas informais em inúmeras situações de observação e/ou escuta de acontecimentos e relatos de experiências de vitimização.

Com a análise desses dados, passei a mapear estratégias adotadas pelos moradores entrevistados para aplacar sua condição de vulnerabilidade. Junto com a equipe de pesqui$\mathrm{sa}^{2}$ nessas ocasiões, filmávamos e fotografávamos suas casas com grades, sistemas de alarme contra roubo, guaritas, enfim todo um arsenal de recursos que visa dar maior proteção ao patrimônio e às pessoas. Preocupava-nos mostrar as adaptações às edificações que transformam a paisagem urbana numa perspectiva que podemos definir como "estética da segurança" ou mesmo "estética do medo", constituindo novas complexidades nos processos de segregação espacial e social que distinguem a

2. Equipe Biev: Ana Luiza Carvalho da Rocha, Cornelia Eckert, Rafael Devos, Olavo Marques. população por critérios múltiplos, como o acesso a bens de consumo e outras lógicas de distinção social.

A demanda maior era por muramentos e grades em residências e em edifícios públicos. O enquadramento intimista que o vídeo permitia produzia uma dimensão "trágica" porque "crítica" da transformação espacial para fins de controle social. Entrevistando as pessoas em condomínios, filmamos os enclaves criados como sistemas de moradias fortificadas, como "fricções de distância" (Harvey, 1996, p. 195) que restringem os projetos rotineiros de deslocamento e de ocupação do espaço privado e público dos habitantes na cidade.
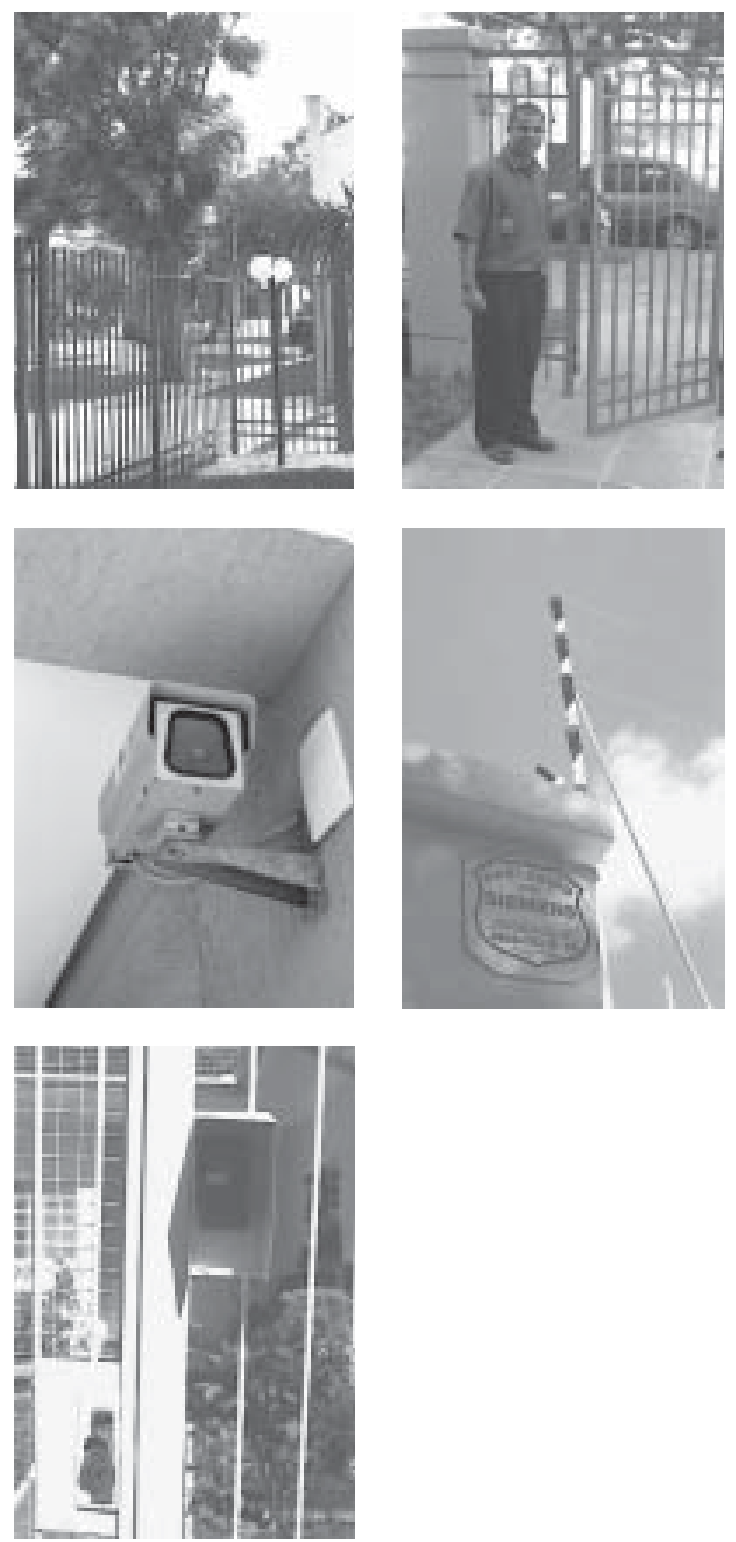
Observamos mudanças cotidianas e um grande aumento por estratégias de segurança. Mesmo os entrevistados que, inicialmente, afirmavam que jamais iriam aderir à fortificação de suas residências acabaram por gradear seu patrimônio após uma experiência de roubo, em um bairro residencial onde até então o modelo "casa-jardim", sem cercas, era o predominante. O professor aposentado Sérgio, por ocasião da entrevista em 1997, respondeu, em tom de desabafo, que capitulara, observando que, após uma longa resistência e luta para manter a imagem de uma sociedade livre sem maiores desconfianças ao Outro, rendia-se à "estética do medo", optando por gradear sua casa a fim de dificultar a possibilidade de um novo furto.

Há, nesse contexto de discursividades, uma construção social do medo, de transformações nas práticas temporais e espaciais de citadinos em suas rotinas diárias em busca de estratégias de mudança de estilo de vida para a redução de riscos oriundos da criminalidade, como furtos e roubos. A dinâmica das ações criminais na condição urbana brasileira é de alta monta, mas longe estamos de uma ecologização da cidade em função da criminalidade. Há, antes, formas de espacializar um processo de transformação relacionada à perspectiva de criminalidade contra o patrimônio e a pessoa física. É a banalização da vida nos roubos seguidos de violência que é temida pelos entrevistados. Essa banalização é reforçada nos noticiários e discursos da imprensa porto-alegrense sobre o tema, dimensionando situações de vitimização que geram insegurança e medo.

Buscando analisar o contexto dessas experiências, descrevemos aqui alguns dos episódios que nos parecem significativos para tratar desse tema:

\section{Episódio 1}

Experiência narrada em 1999, pelo casal dona Jovina e seu Clécio, ambos com 70 anos de idade, brancos; ela, dona de casa e ele, funcionário público aposentado, moradores de um apartamento em bairro de camada média baixa. O edifício é cercado com grades e fios de alarme anti-roubo. Demonstram uma experiência de vitimização ao patrimônio que os marcará para sempre e que influenciará no abandono da casa construída no início da vida de casal como projeto familiar com certa qualidade.

O relato de dona Jovina é difícil, dado o grau de emoção que as lembranças do episódio provocam. A casa fora arrombada, e todos os objetos de valor material e simbólico roubados ou destruídos. A falta de confiança para continuar residindo em uma casa que apresentava vulnerabilidade levou à compra de um apartamento em edifício com "certa" segurança. Ao ser questionada sobre o porquê da escolha de um outro bairro para residir, respondeu ter ficado deprimida e querer apagar da memória esse trauma do imprevisto. $\mathrm{O}$ abandono da casa foi o enterramento de uma época enriquecida por objetos que falavam de suas histórias de infância, de noivado, de casamento, de batizado dos filhos, de heranças e de objetos adquiridos em uma condição de trabalho, economias e privações pessoais. A opção por um apartamento foi para eles a solução imposta para se distanciarem de uma experiência traumática.

\section{Episódio 2}

Dona Gleci, branca, com cerca de 70 anos de idade, residente em bairro central definido como centro político administrativo devido à proximidade ao complexo político-administrativo do Estado, conta, em entrevista realizada em 1998, que passara por várias situações de arrombamento, seja em seu apartamento em Porto Alegre, seja em sua residência no litoral gaúcho. Relata que, na primeira experiência, chegara a registrar queixa na polícia, mas nas ocasiões seguintes não recorrera mais à denúncia por "não adiantar nada". Após a última agressão, optou pela adesão a grades nas portas e janelas em seu apartamento e aramado na casa da praia. Também fizera uma espécie de "chá-de-panela" entre as amigas da terceira idade, "por brincadeira", e todas trouxeram panelas e utensílios para repor suas perdas. Mais recentemente (2002), sua vizinha havia sido vítima de roubo e, aqui, introduziu a questão da desconfiança à ação de trabalhadores eventuais no edifício, como pintores, faxineiros etc. Em suas palavras:

"Teve um apartamento que andaram abrindo, da vizinha. Mas descobriram que foi nosso próprio zelador que armou. A moça tinha muita confiança nele e deixava a chave com ele. Então ele entrou. Mas agora tá mais controlado. Tem serviço terceirizado de porteiro, alarme, porteiro eletrônico e ninguém sobe direto". 
Finaliza comentando ter hoje mais segurança no edifício após o contrato de vigilância 24 horas e cerca eletrizada em torno do edifício, o que não evitaria totalmente uma condição de vulnerabilidade em face do imprevisto. Costuma avisar os filhos casados e mesmo os vizinhos mais próximos sobre seus deslocamentos, sobretudo viagens à praia ou saídas noturnas.

\section{Episódio 3}

Relatamos uma situação observada em uma solenidade pública, de cunho político, seguida de coquetel, ocorrida numa noite em 2003. Após o cerimonial, um guardador de carros previamente contratado comunicou aos participantes - de grupos médios, comerciantes, intelectuais e políticos - que houvera um arrombamento a um veículo que estava estacionado fora de sua alçada de vigilância nas proximidades do local do evento. O carro havia tido seu vidro quebrado, a frente do rádio e discos roubados, documentos espalhados pelo chão. Várias pessoas correram para identificar o veículo e conferir a identidade da vítima. Após a identificação, o proprietário e alguns espectadores permaneceram, e os demais retornaram para a continuidade da festa. O proprietário seguia recuperando seus pertences e conversava calmamente com os meninos de rua que se aproximaram para dizer que haviam visto o autor do arrombamento. Quem assistia à cena, ficava em dúvida quanto à veracidade da versão dos meninos. Observo o início de uma negociação dos meninos junto à vítima. Diziam ser possível identificar o agressor em troca de alguns trocados. Entre os espectadores, frases como "a polícia foi avisada?" não abalava o contexto de negociação. A conversa em tom calmo continuava. A vítima se conformou com a perda e sugeriu terminar o episódio. Os meninos acabaram por encontrar "sem querer" a frente do rádio e um e outro documento. Uma parenta do vitimado tentou chamar a polícia pelo celular; o chamado não foi atendido. $\mathrm{O}$ vitimado deixou o carro arrombado sob os cuidados do vigilante oficial e, junto aos demais espectadores, retornou à festa, enquanto os meninos continuaram perambulando e "zelando" pelos carros para futura recompensa.

Uma discussão entre familiares e participantes do evento se estabeleceu aqui e ali, avaliando que o erro do proprietário teria sido deixar o carro estacionado ao ermo e não possuir alarme. Comentários e sugestões sobre comunicar a polícia para fins de estatística ainda eram feitos, mas sem efeito prático, pois ninguém demonstrava ânimo para enfrentar uma ocorrência policial. A violência ao patrimônio aqui não provocou vítimas fatais. A banalização do acontecido situa-se na continuidade dos festejos.

\section{Episódio 4}

Inventário temático em imprensa local: notas de análise de conteúdo

A imprensa porto-alegrense cobre de forma intensiva as situações criminais e policiais que envolvem conflitos políticos sobre a segurança do Estado e da cidade de Porto Alegre de modo geral, apontando "a crise" e os embates internos entre as corporações policiais. Um evento criminal ocorrido no início do ano de 2001, em uma gráfica na Rua Protásio Alves, em Porto Alegre, evidencia essa crise. Trata-se de um assalto seguido de tomada de reféns (mas sem vítimas fatais). O local foi cercado por policiais. A imprensa fez-se presente e transmitiu ao vivo o episódio com requintes de espetacularização. Os criminosos, com seus reféns, respondiam às negociações. No "palco", a certa altura da situação, policiais civis e militares se desentenderam sobre a quem caberia a hierarquia maior no encaminhamento da negociação. Os policiais expuseram esse conflito de poder diante das câmeras, enquanto as vítimas, os assaltantes e os milhares de espectadores observavam atônitos o desenrolar dos acontecimentos.

Justapondo os relatos e as entrevistas que desenvolvemos a partir de 1997, há uma recorrente referência à condição de vulnerabilidade que se mistura às imagens de banalização e culpabilização dos órgãos públicos pela inoperância de políticas de erradicação do crime. Privilegiadamente, remete a violência a um mesmo e único processo, cuja matriz, simbolicamente compartilhada, seria a decadência da cidade, a degradação dos valores éticos, que geraria a crise da civilização urbana. Entre os entrevistados de mais idade, pode-se constatar a tendência de se referirem ao passado como sendo tributário de um tempo de bem-estar das camadas médias em Porto Alegre. Esse é o caso de seu Everton, entrevistado em sua residência, em 1999. Mora com sua esposa; os dois filhos, já casados, residem em suas respectivas residências. 
Seu Everton nasceu no interior do estado e veio aos 15 anos para Porto Alegre morar na casa dos avós para realizar o curso colegial. Conta que já em 1957 trabalhava no centro, na empresa jornalística Caldas Júnior. Fez jornalismo e permaneceu na empresa até sua aposentadoria. Relata que

naquela época quem entrava na empresa só saía de lá morto, não tinha troca-troca de pessoal. Eu era o mais novo, mais novo que o contínuo, que tinha 22 anos. Aí eu comprei um apartamento perto, pra poder ir a pé para o trabalho. Era uma beleza. Eu tinha um fusquinha que dormia na rua. Só pegava pra viagem. Não tinha problema nenhum, meus filhos brincavam na rua, passava bonde tipo gaiola, era um espetáculo. Aqui era uma rua bem-vista. Perto da igreja, do solar dos Câmaras, tradicional. Naquela época era bom mesmo. Eu cansava de sair ali passear no centro, olhar vitrine, de noite com a gurizada. Era um baita programa. Sem pensar em assalto nem nada. Agora é este terror. Eu tinha dois empregos, andava de madrugada a pé, nada. Hoje só saio pra passear no shopping. Tá vendo aqui? [mostra a janela atrás das cortinas], tá tudo gradeado. Não tem mais condições.

Outra entrevistada porto-alegrense (em 1997 e 1998) foi dona Ana, 67 anos. Reside em um prédio datado de 1970, no centro da cidade. Mora hoje com o marido, a filha e uma neta e faz questão de registrar que é moradora do centro há 54 anos. Durante as entrevistas, dona Ana gostava de falar das vantagens de residir no centro, explicando que essa opção estava ligada à proximidade com o quartel. Seu pai era militar e ela se casou com um militar e, por esse motivo, sempre residiu próximo à zona militar. As vantagens só encontravam um porém ao orientarmos a conversa para os problemas de ali morar. Declara então gostar das facilidades que a modernidade trouxe, menos "esta história de violência".

A década de 1980 é identificada como sendo o período de emergência da violência na capital, com relatos de maior presença de "descuidistas" (ladrões de carteiras) nas ruas e de aumento de assaltos à mão armada e de insegurança.

Dona Ana faz questão de lembrar do passado para situar as diferenças para um tempo presente e situa:
Me lembro de que naquela época nunca se ouvia falar em assim assaltar e atacar. Lembro que quando eu fui estudar no Instituto de Educação, eu tinha 12 anos, uma vez me falaram para ter cuidado com um cara que era exibicionista. Mas aquilo era a coisa mais grave, assim, que acontecia. A gente saía de casa e encostava a porta assim só com o trinco. Ninguém entrava ou roubava. Todo mundo se conhecia [...]. E tinha amigas de colégio público, gente pobre, mas até a miséria era diferente [...]. Tinha era muito preconceito. Moralismo, né! Não tinha isto de uma moça sair na rua sozinha. Mas era pra gente não namorar. Isso aí era muito severo. Mas assalto, essas coisas não tinha. Não tinha esses maloqueiros, essas coisas, isso não tinha.

De fato, é sobretudo na voz das mulheres idosas que surge o paradoxo de avaliarem o atual contexto cultural como emancipado de ordens e proibições sociomorais inculcadas durante tantos séculos e como uma atual condição de vida dominada pelo sentimento de insegurança que lhes solapa formas lúdicas de interagir, sobretudo nos espaços públicos. Ao falarem de suas infâncias e adolescências marcadas pela repressão moral, dimensionam a superação de outros medos e opressões, esses subjugados pela ordem tradicional e por constrangimentos associados aos atos afetivos. Como mostra o relato de dona Ana, superados antigos sentimentos de vergonha e ressentimentos morais graças às ações de movimentos culturais e direitos civis compondo novas formas de relacionamento familiar, o medo às regras morais foi substituído por medos de outra ordem:

Olha, o perigo de violência eu fui sentir de uns dez anos prá cá. De uns dez anos a gente não tinha medo. Medo era assim de andar em má companhia, de ficar falada. Deus o livre uma moça ficar falada, tava na desgraça.

Nessas falas, a crise pela emergência da cultura do medo pela vitimização parece mais conflitiva justamente por se constituir na contramão da ideologia da emancipação das vigas sólidas da disciplina moral e da conduta econômica, que erigiram a família nuclear nos dois últimos séculos de industrialização e urbanização. 
Trago também a experiência de Elenora e Roberta, entrevistadas em 1999, com média de 55 anos, com histórico pessoal ou familiar de militância política. Cotejam as experiências de vitimização recentes a situações diferenciadas de terror, vividas no passado de ditadura militar, pela perseguição política à esquerda entre os anos 1960 até 1980. Em seus relatos, tendem ao inconformismo de ver limitado, após anos de enterramento dos fantasmas da ditadura, o prazer da liberdade de ir e vir nos lugares públicos de suas rotinas urbanas. Roberta explica que hoje, eventualmente, contrata um serviço privado de "van" para levar e trazer a filha adolescente de festas noturnas.

Elenora corrobora relatando sua experiência. Diz que, em sua infância e adolescência, morou em bairro periférico, Azenha, que explica ser um dos bairros mais antigos da cidade:

Morava na Eurico Lara, perto do Grêmio [Futebol Clube], no conjunto habitacional Castelo Branco. Tudo era muito calmo e difícil quem não se conhecia. Depois [...] eu já tinha passado poucas e boas na ditadura [...]. A droga era outra. Depois esta zona virou passagem de maloqueiros para os bailes, aí havia muita boate, ali na João Pessoa. Eu já presenciei ' $\mathrm{n}$ ' coisas de briga, gente bebendo se drogando. Eu já vi se matando, só de espectadora, tiros e tudo. Hoje para se chegar em casa é perigoso, embora tenha até nos prédios zeladores e, eles, botaram grade e tudo. Mesmo assim [...] tem que cuidar . A Alicia quando vinha da faculdade [a filha] que ela estudava à noite, eu ia buscá-la onde ela descia do ônibus. Então é uma série de cuidados que antigamente a gente não teria essa preocupação e hoje se tem, de uns cinco anos pra cá. No meu tempo, na faculdade, a gente fugia da polícia e hoje tu foge do ladrão.

De fato, a busca por maior segurança é uma empreitada que detém um projeto de segurança, de sentidos compartilhados com os outros citadinos numa série de experiências com uma intencionalidade na relação com a cidade. Como dimensiona Alfred Schutz, as ações, os comportamentos aqui se apresentam como experiências em que os sujeitos reconhecem o significado. Experiências que, na interface da cultura do medo, colocam-se como "motivo a
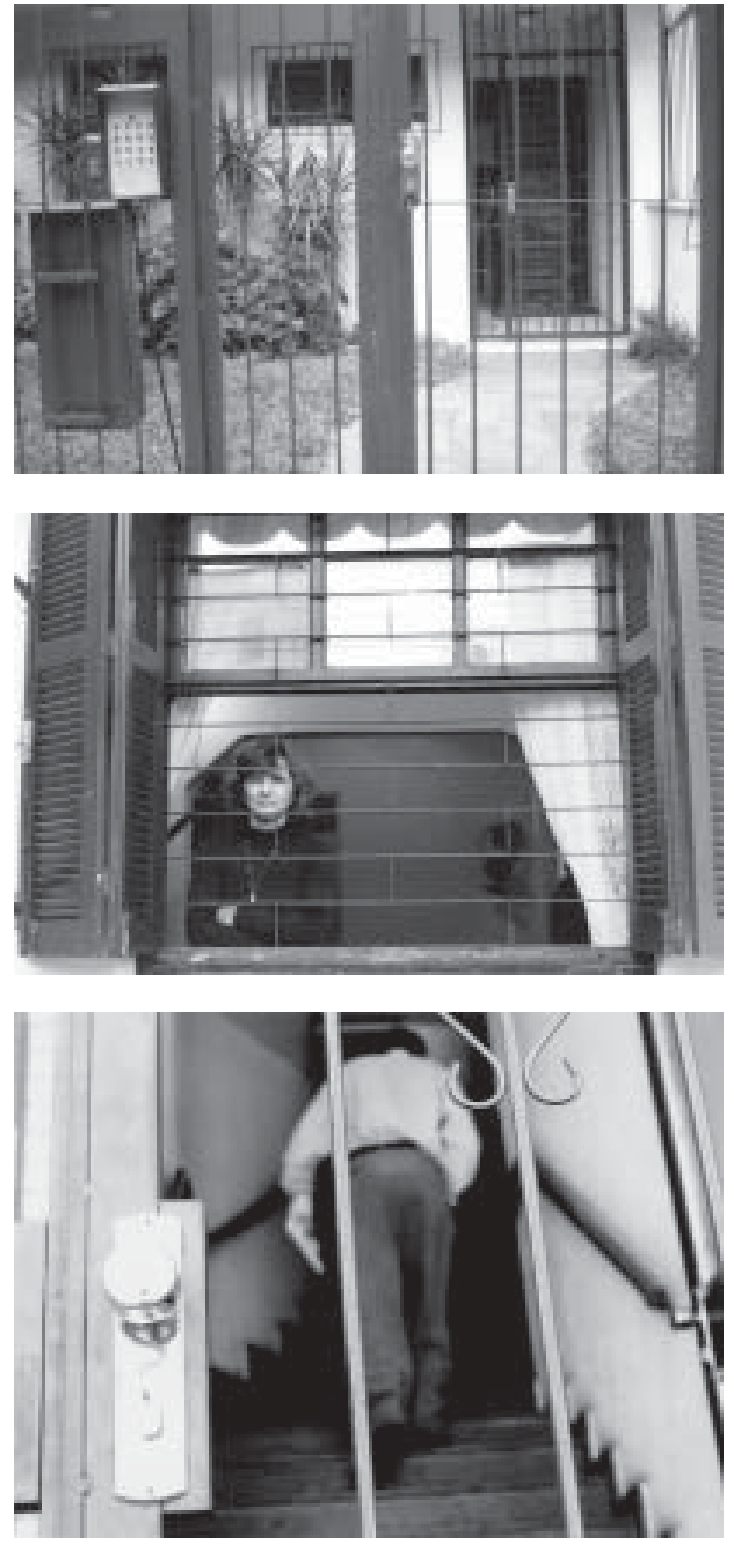

fim de" construir estratégias "porque" envolvem, numa perspectiva compartilhada, a restituição do sentido de continuar a ser, em face da vulnerabilidade no âmbito de complexas estruturas da criminalidade na cidade (Schutz, 1979, p. 123-142).

\section{A cultura do medo}

Uma série de estudos sobre violência urbana no Brasil nos antecede e nos orienta em nossas demandas intelectuais para tratar, neste artigo, do fenômeno da vulnerabilidade dos citadinos em face do aumento da violência nas cidades brasileiras. Gilberto Velho, Ruben Oliven, Alba Zaluar, Tereza Caldeira e Luiz 
Eduardo Soares, entre outros, examinam a violência a partir de uma perspectiva da ordem cultural, seja considerando a ação discursiva dos meios de comunicação de massa e a interiorização de representações que orientam sistemas simbólicos de ação cotidiana do viver na cidade, seja analisando a construção de narrativas dos citadinos que contêm um nível de produção e reprodução da cultura do medo.

Uma condição que situa a violência, nos termos de Eduardo Soares, numa linguagem compartilhada, a partir da qual temos pensado os limites da sociabilidade, a sua crise e suas possibilidades (Soares, 1995, p. 1), coloca o medo e a insegurança como determinismos socializadores cada vez mais presentes no convívio urbano.

A adesão a estratégias de maior proteção, seja pelo consumo em um mercado de segurança, seja pela mudança de hábitos e estilo de vida, leva-nos a analisar o medo como "valor" presente nos processos de representação social sobre a vulnerabilidade pessoal em face do aumento indiscriminado da violência urbana, obrigando os habitantes a espreitar suas práticas sociais num quadro de probabilidades de riscos, o que empresta a imagem de sujeição a formas individualizadas de vitimização.

Se considerarmos os fracassos de políticas econômicas em contextos urbano-industriais, como no caso brasileiro, em que a pobreza continua mantendo proporções alarmantes (Caldeira, 2003, p. 51), importa evidenciar um Estado limitado em sua política de segurança, sem controle eficaz sobre a deterioração dos direitos à liberdade na condição pública. Tal situação implica, nos termos de Tereza Caldeira, uma contraposição às tendências democráticas no país, que finaliza por sustentar uma das sociedades mais desiguais do mundo (Caldeira, 2003, p. 56).

Nesse sentido, o cotidiano do viver na cidade é constituído pelo paradoxo de um ideal civilizatório de construção social de uma realidade remetida à liberdade de individualização agora encompassado pela configuração do sentimento de medo, real, imaginário ou potencial.

As mudanças de hábitos coletivos na cidade são sistematicamente tornadas públicas pelos órgãos de segurança como precauções necessárias a serem tomadas pelos cidadãos para a diminuição da vulnerabilidade e de exposição ao fator de risco. Essas orientações definem as atitudes "facilitadoras" de atos criminosos.

As orientações mais freqüentes falam de mudanças na condição pública e na condição privada. As principais recomendações referemse a condutas que visam transformar o desempenho do citadino em seu ato de habitar a cidade; são ações que orientam a construção da realidade do mundo da vida diária. Dessa forma, através de folders e site, a Secretaria da Justiça e da Segurança no Estado do Rio Grande do Sul orienta as seguintes políticas regulativas de condutas preventivas:

Em vias públicas:

Não transite a pé portando valores elevados em dinheiro ou jóias. Caso se sinta perseguido, entre em um estabelecimento.

Ao retirar dinheiro do banco, guarde-o cuidadosamente e não conte dinheiro em público. Ao ser perseguido por alguém, aja com naturalidade e busque ajuda.

Conduza sua bolsa de forma firme e porte-a na frente do corpo.

Carregue seu celular de forma discreta.

Evite andar em ruas com pouca iluminação.

Não use carteiras no bolso de trás.

Não ande com todos seus documentos e cartões de crédito.

Evite ficar sozinho em paradas de ônibus.

Evite ficar conversando ou namorando dentro de carros à noite.

Ao sair do carro, não deixe pacotes ou bolsas no seu interior.

Não porte rádios ou CDs no carro ou use os de gaveta.

Utilize travas de segurança no carro e saiba de cor a placa do seu carro.

Não ande de carro com janelas abertas e tranque bem as portas.

Em ônibus com poucos passageiros, sente-se próximo ao motorista e separe o dinheiro da passagem para não ostentar sua carteira na hora de pagamento.

Ao ter que parar a noite em semáforos, fique atento ao retrovisor e mantenha o veículo a uma distância razoável do carro da frente. Essa providência facilitará o arranque em caso de emergência. 
Esteja atento a cotoveladas, empurrões ou conversas banais nos coletivos. Essas atitudes podem significar o início de um crime.

Em caso de assalto

Não reaja. Não faça gestos bruscos. Mantenhase calmo. Não tente fugir. Forneça o que exige o criminoso, mas alerte seu assaltante dos gestos que pretende realizar.

Quando possível, chame o 190 ou procure a delegacia mais próxima.

Não use armas.

\section{Em casa}

Instale grades nas janelas, olho mágico e trancas nas portas.

Não forneça dados pessoais por telefone.

Mantenha sempre à mão os telefones de emergência.

Procure conhecer seus vizinhos e seus hábitos. Mantenha controle das cópias da chave de sua casa.

As crianças devem ser orientadas para não abrirem portas aos estranhos.

Ao sair ou chegar em casa, fique atento. Essas ocasiões são as mais propícias para roubos e seqüestros. Se desconfiar, aguarde, dê uma volta no quarteirão e chame a Brigada Militar no 190.

Tranque bem as portas e janelas antes de sair. Ao viajar, suspenda assinaturas de jornais e revistas ou peça para alguém de confiança recolhê-los.

Selecione criteriosamente os prestadores de serviço a sua residência. Exija referências anteriores.

Atitudes paliativas de toda ordem remetem a um regramento de condutas, apreendidas como experiências em curso de novas estratégias de sociabilidade e estilo de vida. A reclusão à intimidade do lar passa a ser uma atitude recomendada, ou a saída comunicada a familiares e amigos, uma precaução, criando uma espécie de rede de vigilância solidária no acompanhamento do trajeto do sujeito, desde o nascimento do deslocamento até sua finalização, que significa o retorno ao lar tendo a integridade física assegurada.

O receio resulta de um processo de contato agressivo a partir do outro que desestimula o indivíduo no que lhe é constitutivo: as interações que o constroem como sujeito social. Reféns do estranhamento, indivíduos em suas redes de pertencimento designam como perigosos as territorialidades, os trajetos, as situações, os horários e os indivíduos que, potencialmente estranhos, ameaçam a ordem social. A desconfiança do outro leva ao mergulho no sentimento de esvaziamento dos sentidos coletivos, fortalecendo ainda mais as bases de um ethos social hiperindividualista.

Os percursos residenciais, os projetos de vida, os cálculos utilitários que antecipam uma relação com territórios públicos na cidade são delineados por essas determinações externas.

Os denominados "medos domésticos" (Roché, 1993), como o de trancar-se em casa "a sete chaves", o não-atendimento à porta, o aumento desmesurado da proteção do domicílio, combinam-se com os "medos no espaço público", medo do estranho, medo do assalto, numa espécie de agorafobia. Ambas as formas de configurar as inquietudes são correlatas com a expressão de um medo que se afirma na subjetividade - "eu estou inseguro" (Roché, 1993, p. 150).

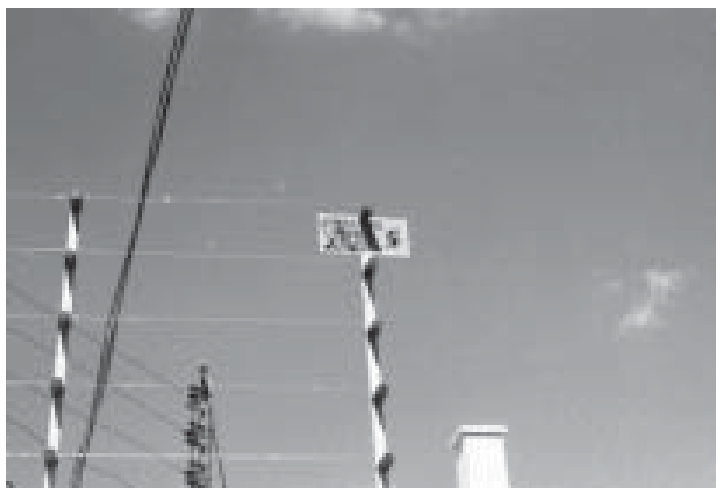

As medidas de segurança adotadas no agenciamento da vida urbana são cada vez mais expressas e divulgadas em estatísticas e demonstrativos quantitativos realizados a partir de sondagens que conformam valoradamente a discursividade em torno de uma racionalidade probabilística. André Burguière pontua que "em nossas sociedades, o sentimento de insegurança aumenta com o reforço objetivo das medidas de proteção", em que "toda medida de proteção enquanto tal é indicação de ameaça e atualiza a própria ameaça" (Rouché, 1993, p. 115). 
Sem mascarar as contradições impostas pelo caráter "disjuntivo da democracia brasileira" (Caldeira, 2003, p. 56), a insegurança, pela teoria de risco, pressiona condutas e atitudes que implicam restrições de liberdade individual.

\section{Condição de riscos ou neoconflitos?}

Diversos estudos convergem na necessidade de investigar sobre uma mudança de atitudes e valores no universo de segmentos urbanos diante de uma cotidianidade em que esses segmentos precisam lidar com a violência e o sentimento de medo que nascem da criminalidade urbana. A antropóloga brasileira Alba Zaluar, em seu texto Medo do crime, medo do diabo, chama a atenção para os textos de jornais diários que trazem manifestações de indignação dos moradores amedrontados, "que vivem atrás das grades de suas residências e dos vidros de seus automóveis, conclamando todos para o fim da passividade, sem dizer como fazê-lo" (Zaluar, 1994, p. 6).

Numa primeira aproximação ao tema do imaginário em torno do ente/entidade culpado(a) das mazelas da violência urbana, pode-se constatar ainda que, não raro, no senso comum, a tendência é conceber o "inimigo" na figura genérica do "pobre", o Outro que ameaçaria uma irreversibilidade na crise urbana. O deslize para um sistema de acusações é perigo ideológico iminente, como analisado por Tereza Caldeira sobre a fala do crime (Caldeira, 2003, p. 43) entre moradores na cidade de São Paulo.

Tomados pela desconfiança do Outro e pela insegurança cada vez mais inevitável, progridem as pressões reivindicatórias sobre as instituições estatais contra os riscos do viver na cidade. As queixas dos citadinos, de modo geral, são apropriadas por instituições oficiais de poder (governo, polícia, exército) como razões legítimas para atitudes punitivas violentas, assim como para outras formas de repressão e de exclusão.

Uma outra feição da crise cinge, então, a qualidade de vida da comunidade: poderes legais incitando a um aumento da violência no combate à própria violência ou, como sugere Hannah Arendt (1994), admitindo que cada diminuição de poder é um convite à violência.
Importa, assim, considerar a construção do medo social pela imprensa, pelo mercado de segurança, pelas políticas públicas e pela ação cotidiana dos habitantes na busca de diminuir suas vulnerabilidades à criminalidade na cidade no âmbito das teorias reflexivas do risco, aproximando-nos, por exemplo, de Mary Douglas, que afirma que vivemos, hoje, numa sociedade de riscos, reveladora de uma nova cultura individualista relativa ao quadro de determinações abstratas e universais no qual os riscos se tornam fatos sociais (Douglas, 1992).

Ao analisarmos os riscos que se tornam fatos sociais (Douglas, 1992), a consciência do aumento da vulnerabilidade e a diminuição da probabilidade de segurança patrimonial e pessoal, acompanhamos Ulrich Beck (1992) e Anthony Giddens (1991) em suas críticas a políticas institucionais na era industrial e em sua análise do surgimento de peritos para mediar as situações de risco.

Para esses teóricos, a violência urbana, como risco em potencial, alimenta um mercado de segurança e promove a qualificação de especialistas nesses riscos. O acesso ao conhecimento dos riscos, por parte da população, converge com projetos de "conscientização" do estado de violência para prevenção ao perigo, cuja reflexividade, no sentido de Giddens ou Beck, consiste na identificação dos efeitos e perigos pela dinâmica de radicalização da modernidade com uma profunda crítica à crise institucional.

Podemos observar esses esforços de programas de conscientização em projetos governamentais do estado e da municipalidade de Porto Alegre no chamado programa de "Orçamento Participativo", vinculado ao projeto do governo que dirigiu por mais de uma década (1989-2003) ambas as instâncias políticas. Também a atual estrutura governamental mantém o tema da segurança da cidade como prioridade a partir da atribuição de secretarias, dando continuidade aos projetos já iniciados na Secretaria da Justiça e da Segurança, que trata do estado, e da Secretaria de Direitos Humanos e Segurança Urbana, que trata do município.

Entretanto, o desafio apresentado pela criminalidade organizada do narcotráfico evidencia os limites de programas de combate ao crime 
pelos órgãos responsáveis pela segurança pública, como mostram pesquisas sociais e governamentais. Por um lado, o aumento de ação para conter os delitos por repressão pouco diminuiu o índice de criminalidade; por outro lado, esses organismos são reféns dos processos de corrupção da própria estrutura repressiva, perpetuando a incapacidade de instâncias políticas de combate à criminalidade $\mathrm{e}$ a disputa de poder nas diferentes polícias que atuam no contexto urbano, mostrando que as raízes dos problemas sociais no contexto brasileiro são mais complexas e implicam reformas estruturais na base do sistema da justiça, ultrapassando o sistema atual, comprovadamente obsoleto. A essa ambigüidade se soma o papel dos meios de comunicação, que se especializam em espetacularizar a violência na cidade, gerando um sentimento de medo e pânico na população.

Em face dos limites públicos em prol da coletividade, é na ação preventiva da população que se protege que encontramos o ato cultural de confrontar a crise dimensionada na criminalidade. Essa ação preventiva dos indivíduos alinha-se às propostas de sistemas de segurança e de políticas de proteção social, definidas por planos governamentais de segurança urbana, com a orientação de regras de conduta para a obtenção de segurança com o objetivo de diminuir a fragilidade em face do dilema da criminalidade na cidade.

A sistemática limitação das instituições de ordem e do sistema judiciário e a urgência nas mudanças do caráter disjuntivo da democracia brasileira (Caldeira, 2003, p. 55) expõem a visibilidade do aumento da vulnerabilidade do citadino, cuja prática cidadã ameaçada condiz com a ineficiência da representação institucional pública, que deveria representar os interesses da sociedade como um todo (Beck, apud Guivant, 1998, p. 27). A população é alarmada para se proteger.

A indústria oferece paliativos instrumentais. As serralherias especializam-se em correntes e chaveiros, grades, portões automatizados e pantográficos, estruturas metálicas e basculantes. Dado seu custo acessível, essa opção transforma-se em fonte de consumo de todas as camadas sociais. Já as "lojas de segurança especializadas" propõem uma parafernália de instrumentos antifurto: câmeras para circuito interno, sensores internos e externos etc.

Mas a maior demanda de moradores em bairros de camadas médias é a de vigilantes diurnos e noturnos, alimentando um mercado de grandes proporções. Em 2005, foram indicadas pelo Sindicato dos Vigilantes em Porto Alegre 122 empresas no estado, com registros legais, e 140 empresas prestadoras de serviços de vigia sem registros legais.

Essa prática consiste em reunir-se um grupo de moradores, em geral nos limites geográficos da "quadra", que contrata o sistema de vigia. Para isso, é instalada uma guarita na calçada, de forma que o vigilante possa observar constantemente a rua. Ainda segundo o Sindicato dos Vigilantes, é provável que estejam atuando 18 mil vigias atualmente na cidade. Eles não podem portar armas, e sua função preventiva é de, pela ação de vigilância, dificultar a ação criminal.

Esses peritos em vigilância seguem um curso de formação antes de assumirem tal função, única forma de atuarem na legalidade, vinculados a empresas de segurança desarmada, atuando nas ruas, portarias e zeladorias fiscalizadas pelo Grupamento de Supervisão de Vigilância e Guardas, setor da Brigada Militar do estado. De modo geral, os condomínios e edifícios em Porto Alegre contratam serviços terceirizados no sistema de segurança privada desarmada, com circuitos internos e externos de câmera para controle televisivo. Já moradores de uma quadra cotizam as despesas para contrato de vigias autônomos também denominados de "guardas de rua", que se revezam durante turnos diurnos e noturnos. Para comunicação com a polícia, usam telefones celulares do vigia contratante, telefone na guarita ou telefone de algum morador. Essa prática não se diferencia muito da prática dos antigos guardas noturnos. A diferença é que, antes paga por recursos municipais, é agora de responsabilidade dos moradores.

O posto de vigia de seu Oswaldo (55 anos, branco) fica em frente a um grupo de casas e edifícios em zona residencial de classe média. Iniciou essa atividade em 1997 e logo solicitou aos moradores "da quadra" uma guarita. Essa é feita de fibra, com três janelas e uma porta, a 
qual permanece aberta durante o dia e fechada à noite. No seu interior, uma cadeira. O método de vigia consta em percorrer a quadra para cima e para baixo, observando a aproximação de qualquer pessoa estranha ao território. Os vigias são organizados em três turnos. Durante o dia, conversam com os moradores e são conhecidos dos zeladores de todos os edifícios. Toda a quadra é gradeada, e muitas casas apresentam ainda sensores e câmaras antifurto e têm cachorros ferozes.

O ônus da vigilância passa, assim, de forma sistemática a ser cotizada entre os habitantes da cidade, privatizando os processos de segurança e criando a demanda de peritos em vigilância para mitigar os atos criminais.

No caso de famílias mais abastadas, o microchip cutâneo é um recurso para solucionar casos de seqüestros. Em Porto Alegre, 22 famílias estão inscritas no programa, que depende de uma base de monitoramento. Outra demanda é de empresas que buscam e levam adolescentes e mesmo adultos para eventos de diversão noturna. Essa opção é cada vez mais freqüente, substituindo a cotização entre pais que se revezam no leva-e-traz de filhos e amigos dos filhos às festas noturnas. A exigência de carro blindado torna o recurso pessoal mais limitado, e o contrato de empresas especializadas em carros blindados é recorrente. Muitas vezes, são as mesmas empresas que atuam em transporte escolar, as quais já adquiriram confiança no mercado, que operam nesse ramo "promissor".

Essa expansão do mercado de consumo, da indústria da segurança e de especialistas engendra a necessidade de estratégias de segurança consideradas lógicas ao enfrentamento dos riscose remete às noções propostas por Giddens de "construção da reflexividade" (Giddens, 1991, p. 43) e, por Beck (1992), de "modernização reflexiva", em que a seleção individual por uma ação protetora objetiva minimizar a ameaça do perigo, demonstrando, assim, a recomposição de uma confiança pela mediação do mercado em detrimento da credibilidade nas instituições públicas e civis.

As experiências de vitimização na rede de relações e o acesso à imagem do medo divulgado pela imprensa e pela publicidade de segurança remetem a uma reflexividade pela constante multiplicação do consumo da segurança e mudanças no estilo de vida reorientadas por práticas de prevenção. Nos termos de Giddens, estamos diante de um desencaixe dos sistemas sociais pelo dinamismo da modernidade de "separar tempo e espaço e recombinar esses em formas que permitem o 'zoneamento' tempo-espacial preciso da vida social", de "reordenação reflexiva das relações sociais à luz das contínuas entradas de conhecimento, afetando as ações de indivíduos e grupos" (Giddens, 1991, p. 25).

Sucessivas situações e experiências vividas ou apreendidas passam a ser sistematicamente avaliadas como decadência social devido ao caos constituído pela criminalidade urbana.

Essas redefinições dinamizam diferentes formas de busca de proteção. O diálogo se faz necessário entre as vítimas e a sociedade. Surgem organismos não-governamentais organizados por vítimas ou familiares de vítimas fatais, que demandam do interesse público arenas de atuação para compreensão dos processos de vulnerabilidade estrutural e de mediação política, como o Centro de Referência às Vítimas de Violência, ligado a instâncias municipais de serviço de segurança pública.

$\mathrm{O}$ risco da insegurança situa-se, portanto, como um processo sociocultural relevante no contexto da cidade brasileira e, no nosso estudo, em Porto Alegre, não só apreendido pelas dinâmicas de probabilidades estatísticas de ocorrência, mas como escolha de organização de formas de agir dos atores em sua cotidianidade.

Para Mary Douglas (1982), por um lado, há uma burocracia que busca administrar os riscos orientando as condutas individuais; por outro, também os indivíduos se organizam na elaboração de estratégias de enfrentamento aos riscos. Esses aspectos contextualizam as descontinuidades que exprimem formas agonísticas no viver urbano, os quais delineiam a paisagem da cidade em seus paradoxos contemporâneos.

Podemos considerar que a ação dos atores na cidade busca amainar a vulnerabilidade considerada e se refere à falta de confiança nos administradores da segurança, mas também à desesperança de políticas públicas capazes de instaurar ideais sociais de igualdade e justiça. Aqui podemos nos aproximar da análise de Paul 
Ricoeur sobre estarmos em face de "neoconflitos" (Ricoeur 1988, p. 149), novas determinações socioculturais que alimentam a tentação da busca de uma ordem considerada "caótica" e que afeta a população alimentada de medo e que se coloca na defensiva (Ricoeur, 1988, p. 151). Dessa forma, estamos tratando não só de diferentes formas de racionalidade, mas de uma conjugação de experiências simbólicas complexas que problematizam as trajetórias pessoais e coletivas dos sujeitos habitantes nas cidades.

Esses neoconflitos implicam formas mais complexas de reconhecimento de si nos processos de interpretação da vida social moderna e dos medos coletivos na atualidade, como sugere Jean Delumeau, perseguindo o seu questionamento sobre "do que, de fato, as pessoas têm medo?" (Delumeau, 1989).

Essas formas de expressão das preocupações que habitam os corações e as mentes dos citadinos apresentam-se como narrativas do desejo coletivo de reconstrução de uma ordem perdida, de uma normatividade desfeita, de uma sociedade estranha e incivilizada.

Nesse sentido, não se trata de uma naturalização discursiva da violência, muito presente nos sistemas acusatórios no passado (organicistas e funcionalistas). Há, antes, uma espécie de socialização da violência na indagação sobre a construção da imagem do Outro promovida pela cultura do medo.

\section{A hermenêutica da crise no cotidiano na cidade}

A constante projeção dos atos, dos gestos e das condutas cotidianas nas biografias dos habitantes na cidade nos revela cidadãos em suas identidades reflexivas sobre sua condição de construir disposições de enfrentamento à banalização da violência criminal. A conduta não é só projetiva, é igualmente prospectiva, retrospectiva de ações e pensamentos dos habitantes no fluxo do tempo coletivo. A previsão de estratégias para os citadinos surge como interpretação, reflexão igualmente retrospectiva tecida no estoque de conhecimento apreendido no vivido cotidiano, como crises a serem ultrapassadas.

A crise configurada pelo medo social à violência na cidade, para os entrevistados, refere-se ao tempo presente, em que as formas interativas no mundo cotidiano já não garantem uma previsibilidade das rotinas e interações de reconhecimento do Outro na imagem ideal do prometéico (trabalhador honesto). Manifestam, sim, conhecimento de transformações dos medos sociais que conformam uma geração. Manifestam preocupação por um sistema de valores éticos de referência capazes de reprimir uma crescente agressão ao corpo coletivo na cidade e de dissipar os medos e as ameaças à vida. Mas, ao reivindicar atos e normas reguladoras de tais processos a partir de estruturas de poder político-urbanas, atuam igualmente como estrategistas na construção de alternativas de resguardo social. Sensibilidades que contrastam com imagens de medo de uma outra cidade, porque pertencente ao contexto urbano em "outros tempos". No entanto, como não dizer que há movimento de uma identidade narrativa coletiva de citadinos que, numa polifonia generalizada, pensa-se diferentemente em face das novas complexidades na cidade? Há tessitura de novas sensibilidades, de força coletiva de construção de sentidos em que aparentemente a banalização orquestra uma mídia eloqüente.

Os relatos de experiências de medo à vitimização e a investigação sobre as sociabilidades relacionadas desenham, no contexto da cidade, múltiplas formas de convivências urbanas reorientadas pelo sentimento de insegurança, considerando aqui o conceito de "jogar o social" simmeliano, segundo o qual os indivíduos interagem ou se evitam, se encontram ou se afastam, mas sempre em ação permanente ou passageira. Nesse sentido, a cultura do medo coloca-se como uma síntese singular do espírito subjetivo com o espírito objetivo, concebendo a cultura objetiva e subjetiva sob o ponto de vista do "valor", na dinamização dessas múltiplas formas de convivência. Nessa experiência de medo social, o sujeito é habitante de seu tempo na cidade, e a própria cidade é o sujeito de interação, "sujeito moderno", fugaz, contraditório, paradoxal, dialético, efêmero, mas sempre lá, sujeito-cidade. Disforme, por certo, ou incerto, mas instância viva, nas reciprocidades imanentes do ser sociedade. Alfred Schutz descreve essa corrente de consciência compartilhada no cotidiano vívido como tese geral da existência do 
alter-ego (apud Wagner, 1979, p. 163). Dimensão que remete os habitantes aos jogos de memória que os inserem como atores de uma trajetória coletiva na cidade.

A alteração na tessitura urbana condicionada pelo medo social converge com a mudança de forma do pensar e do viver, conforme orienta Georg Simmel (1934), para quem, na vida cotidiana, precipita-se a figura do terceiro disformante (o conflito) nos atos interativos entre os indivíduos que desenham redes de trocas que estetizam o viver na cidade em suas diferenciações e no seu princípio de individuação.

Georg Simmel (1934), ao conceber a história a partir dos sentimentos dos atores, das representações dos conteúdos de consciência, elucida a afirmação do indivíduo e sua atuação como sujeito no mundo, aqui, como o indivíduo opera a partir das imagens de medo em que se espelham as complexidades de ser sujeito (cidadão) no mundo moderno, relacionando uma ideologia individualista de sobrevivência. Ou, como sugere Gilberto Velho (1987) sobre "a mudança de costumes e valores associada às drásticas transformações da vida urbana", o uso de trancas na portas, o carro com alarme, o guarda (privado) de rua, a evitação no contato social, por exemplo, onde "uma dessas consequiências foi a banalização, rotinização da violência".

A interiorização de uma cultura do medo e da imagem genérica de um Outro ameaçador surge como mais uma matéria da sociação (Simmel, 1983, p. 166), mas que não consegue enrijecer as formas de interação do contínuo viver social em sua descontinuidade pelas mudanças de formas no curso dos códigos sociais, dos processos histórico-políticos, dos constrangimentos estruturais e das práticas dos indivíduos. Isso porque, para Georg Simmel, a reciprocidade implica que o desenvolvimento da cultura é, ao mesmo tempo, uma espécie de deculturação, não no sentido de uma negação, mas de um escapamento da cultura em um mundo objetivo que se torna impermeável a toda subjetividade (Freund, 1992, p. 221). As discursividades sobre insegurança e criminalidade que constroem a cultura do medo, como imagem do viver urbano, constituem-se como sendo esse desencaixe e uma espécie de incomunicabilidade entre o mundo objetivo e o mundo subjetivo, no fluxo do tempo e do espaço. A cultura do medo e a violência desmesurada apresentam-se, aqui, como uma dessas formas criadas pela obra humana cujo controle escapa ao seu criador e que se desformam independentemente da vontade maior de poder reconhecer a lógica da forma para a própria duração individual na história coletiva.

A obra da violência na cidade sobreviveria, assim, à vida de seus autores moderno-industriais. Essa autonomia da desformação, no âmbito do espírito objetivo, torna-se adversária do seu sujeito criador e desafia sua lógica, a ponto de, como diria Sara Pain, confundirmos os reais perigos com os perigos simbólicos. A cultura do medo geraria, aqui, a imagem da tragédia da cultura pela "atitude do vivente a produzir a não-vida" (Freund, 1992, p. 222).

Atores que compartilham sentimentos de insegurança e vulnerabilidade recorrem a ações paliativas e configuram a existência de intrincadas relações. Se há adesão ao gradeamento, se há segregação e afastamento do Outro, estranho, há também motivação de reconhecimento do Outro, há busca de pertencimento, de conformação de redes de interação.

Não há uma homegeneização de sentidos na cultura do medo, antes "retóricas", "táticas", diz Michel de Certeau, uma miríade de ações, todas trazendo em si a marca da intenção humana. Assim, mesmo que atreladas a uma complexa teia de jogos de poder enunciada nas políticas de segurança e estruturas repressivas, há reinvenção nessas condutas, "formas clandestinas assumidas pela criatividade dispersa, tática e paliativa de grupos ou indivíduos já presos nas redes da disciplina" (De Certeau, 1994; Harvey, 1996, p. 197).

Antes de conceber as condutas como resposta a uma malha repressiva de controle social, como denuncia Michel Foucault (1979), elas tornam-se práticas da vida cotidiana, no cerne da contemporaneidade, que ordenam simbolicamente o tempo e o espaço vividos e fornecem prescrições para a experiência, mediante a qual aprendemos quem ou o que somos na cidade que habitamos.

Essa forma de ver ato humano de criação na ação sob a prescrição da cultura do medo é uma fala sobre si para reconhecer um nós 
relacional nos ritmos paradoxais das práticas e saberes do viver cotidiano. Há, aqui, convergência com o princípio metodológico de Georg Simmel (1934), do ato recíproco entre cultura subjetiva e cultura objetiva, em que, se "o processo causal é indispensável", ele não é exclusivo, mas submisso a incertezas e variações de ação e, portanto, sujeito às oscilações das avaliações e escolhas. Dessa forma, não se trata de localizarmos uma população aterrorizada, uma classe média passiva ou uma classe popular encurralada, tampouco de localizarmos a causa da violência, mas sim de reconhecer as ações que projetam a vida aprendendo a tragédia como drama social gerador de sentido para a continuidade na cultura.

$\mathrm{Na}$ interpretação de estado de crise e de ameaça da ordem coletiva, os moradores, os habitantes não raro falam dos constrangimentos na busca diária de enfrentamentos e de táticas para reagir à "crise", "à violência"; respostas simbólicas a garantir a integridade física e sociabilidades que expressam novos estilos de viver suas rotinas e de deslocar-se na ambiência urbana, situações de reconfiguração do imaginário social.

Tentando novamente uma orientação na teoria simmeliana, tornamo-nos conscientes da dimensão da cultura do medo como tragédia da cultura, do viver moderno, e a reproduzimos, mesmo conhecedores da condição de sermos autores de um projeto estéril de continuidade. Mas como dar conta dessa ruína de sociabilidade pela não-sociação? Como poderíamos conscientemente aniquilar a vida que justamente queremos preservar? Ocorre que, nesse processo, não se trata mais de tragédia, e sim de crise. E, se nos acomodamos na tragédia da cultura (adesão à estética da cultura do medo, por exemplo), lutamos para superar a crise (reivindicando direitos civis, por exemplo). Nesse sentido, é da dinâmica do viver social contemporâneo o estar em crise, e a força do viver no social consiste justamente em preencher de sentidos a crise (da cultura moderna, para Simmel), reordenando as experiências temporais num campo semântico que estrutura a vontade de ultrapassar a tragédia inerente à cultura, ou seja, a essência que reside na faculdade de produzir, como vida, as formas não-viventes (Freund, 1992).
Assim, tributária do tempo, a cultura do medo contém sua própria transformação, ora uma conformação, ora uma desformação, mas ora também uma reformulação que a teoria da forma contempla. Essas considerações de Georg Simmel (1934) são debruçadas mais propriamente no inner-self (no plano psicológico, cultivo interior ou sobre a subjetividade), uma vez que, para o autor, o indivíduo qualitativo é a unidade fundamental de análise. Nesse sentido, importa complexificar as questões em torno da cultura do medo no âmbito histórico e social, tal como o propõe Norbert Elias (1994), que interpenetra a sociogênese e a psicogênese, relacionando a história interna de cada indivíduo a uma história de longa duração: o processo civilizatório de domesticação do pensar e de colonização do agir.

No que pese a necessidade imediata de reformas políticas na base do sistema civilizatório econômico e jurídico brasileiro, para brindar a Elias, supera-se a condição de uma crise global de aniquilamento da cultura, como advogam representações sobre a violência urbana de pensamento organicista. Tendência essa que reflete na mídia o retrato de uma sociedade enferma, cujos sintomas são a desordem, e cujas consequiências são avaliadas no senso comum sobre aumento sem par e generalização da violência pela esterilidade de sentidos (Arendt, 1994, p. 55).

A violência urbana em sua proporção agonística não constitui uma nova crise no presente, mas é próprio do fenômeno moderno que a crise engendre o conflito social. A cidade criadora está sempre grávida de sua destruição para transformação e para estetização de uma nova forma de viver o social. Como se trata de uma dinâmica de níveis (seguindo Luis Dumont, 1992), a cidade é morta para se transformar e gerar a criação da duração, não em um sentido linear e progressista, mas em uma oposição de níveis de posição (Dumont, 1992) ou em uma superposição temporal e cíclica (Bachelard, 1989) que não nega uma vontade de ultrapassar a vida, como sugere Simmel (apud Bachelard, 1989). A própria adesão ao mercado de segurança e a segregação espacial acabam por nos dimensionar um ultraje ao direito social (dialogo aqui com Caldeira, 2003, p. 376) e nos questionar sobre o 
conteúdo de liberdade que queremos projetar para que a noção de confiança sustente o viver em sociedade.

A paisagem do mundo urbano contemporâneo guarda, nesse contexto, as feições das crises e dos medos sociais, por um lado, e das estratégias de vida de seus habitantes, seus sonhos e desejos, por outro lado, segundo a acumulação benéfica da animação e da vibração temporal dos ritmos diferenciais de elaboração de sentido de seus territórios de pertencimento, aderindo à fragmentação e à sistemática negociação dos lugares de interação.

Daí a possível leitura, entre outras, da arte de viver o cotidiano a partir das práticas de prevenção, de estratégias de evitação que vão estilizando as interações sociais cotidianas como estilos de vida propulsores de expressões múltiplas de pensar e agir na cidade ameaçada pela criminalidade.

Reconhecer a vulnerabilidade como um fato social retoma a noção da cultura como espaço de relações diferenciadas onde a possibilidade de resistência (résilience) coloca-se diante dessa perturbação sobrevinda pela violência urbana, que solapa o valor "confiança" como lógica do viver urbano moderno-contemporâneo, nos termos de Paul Ricoeur (2000).

A cultura do medo inscreve-se, assim, como mais um valor na memória social que mapeia a condição do viver urbano hoje e que inflama atitudes pelas quais nos relacionamos ao passado e ao futuro, como estratégias do saber viver social que promovem as ações com conhecimento mais coletivo da sociedade que queremos, ultrapassando as reações defensivoagressivas.

A cidade-contexto está ligada à existência da violência, mas não há conformismo na democratização da criminalidade como risco. As práticas e os fenômenos objetivamente identificados como criminosos ou violentos são apenas um dos processos presentes na figuração da cultura do medo. Esta, sim, é analisada a partir da interiorização e exteriorização de formas de percepção e de representação social da ameaça e dos riscos (Soares, 1995, p. 1). Tampouco há positividade na apreensão da cultura do medo como fenômeno social. Apostamos, entretanto, que há circularidade de idéias, de pontos de vista, interpretações nos relatos de experiências, de diálogo e de ações de resistência. Não há só evitação, há gestos de transformação nas relações que nos levam paradoxalmente a nos aproximar do Outro. Uma ONG fundada por vítimas, a necessária corrente de vizinhos e a familiarização com algum Outro próximo são pequenas subversões à imagem do indivíduo alienado e sem qualidades. No fluxo da experiência humana, presente no mundo contemporâneo, repercutem práticas e saberes que os indivíduos e/ou grupos urbanos constroem com a cidade que se transforma.

\section{Conclusão}

Mapear a complexidade da vida cotidiana no meio urbano, seu quadro de situações disruptivas e de desenraizamento coletivo é um impasse que conduz muitas vezes o pesquisador a dificuldades na forma de compreender os graus diversos de concretude que adquire a cultura do medo no mundo urbano contemporâneo, principalmente no caso brasileiro.

Porto Alegre é mais uma cidade onde se reconhece a condição de crise das dinâmicas de transformação social superando sua referência ao progresso e ao atraso social. No jogar o social, como diria Georg Simmel para definir a sociedade, importa situar o esforço da produção de sentido que implique uma coletividade, que recoloque o urbano no social, transformando a defesa em ação por referências de valores de identidade, permitindo aos habitantes construir projetos, encadear trajetórias que os impliquem solidariamente, restituindo a confiança em si.

Trata-se de perceber cenários conflitivos diferenciados por questões sociais e políticas, por diversidades culturais (costumamos dizer), no caso de cidades brasileiras como Porto Alegre, onde a dimensão antropológica, antes de propor certezas, situa-se como o lugar de difusão das interpretações e narrativas de uma sociedade não-aniquilada na construção de uma ética de autocontrole. Movem-se as nuvens. Outros ruídos urbanos. Mas não há como não perceber a força de sentidos dos princípios de reciprocidade que movem a humanidade, mesmo a de Porto Alegre. 


\begin{abstract}
The ethnographic news developed in research in Porto Alegre is brought here aiming at the study of the memory daily life under the fear culture approach due to the crisis situation and violence in the contemporary world, integrated to the plurality rescue perspective and collective memory diversity, and also the urban world ethnographic heritage preservation, according to the different social individuals, having in mind the elaboration of cultural actions in the modern industrial cities which contemplate the memory places of their inhabitants.
\end{abstract}

Key-words: city; memory; forgetfulness; fear; crisis.

\section{Referências}

ARENDT, Hannah. A condição humana. Rio de Janeiro: Forense Universitária, 1991.

Entre o passado e o futuro. São Paulo:

Editora Perspectiva, 1992.

. Sobre a violência. Rio de Janeiro: RelumeDumará, 1994.

ARIÈS, Philippe. O homem perante a morte. Lisboa : Europa-América, 1977.

BACHELARD, G. La dialectique de la durée. Paris : Quadrige/PUF, 1989.

PUF, 1984.

La poétique de l'espace. Paris: Quadrige/

BOSI, Ecléa. Memória e sociedade. Lembranças de velhos. São Paulo: Queiroz Ed./Edusp, 1987.

BOURDIEU, Pierre. La distinction. Paris: Ed. De Minuit, 1979.

CALDEIRA, Teresa Pires do Rio. A política dos outros. O cotidiano dos moradores da periferia e o que pensam do poder e dos poderosos. São Paulo: Brasiliense, 1984.

CALDEIRA, Tereza P. A cidade de muros. São Paulo: Edusp/Ed 34, 2003.

CANEVACCI, Massimo. A cidade polifônica. Ensaio sobre a antropologia da comunicação urbana. São Paulo: Studio Novel, 1993.

COSTA FREIRE, Jurandir. O medo social. Revista Veja 25 anos. Reflexões para o futuro, 1997. p. 82-98.

DA MATTA, R. A casa \& rua. Espaço, cidadania, mulher e morte no Brasil. São Paulo: Brasiliense, 1985.

DE CERTEAU, Michel. A invenção do cotidiano: artes de fazer. Petrópolis: Vozes, 1994.

DELUMEAU, Jean. História do medo no Ocidente. 1300-1800. São Paulo: Companhia das Letras, 1989.

DOUGLAS, M \& Wildavsky, A. Risk and culture. Los Angeles: University of California Press, 1982.

DOUGLAS, Mary. Risk and blame. Essays in cultural theory. Londres: Routledge, 1992.
1966.

Pureza e perigo. São Paulo: Perspectiva,

DUBY, Georges. Ano 1000 ano 2000, na pista de nossos medos. São Paulo: Unesp.

DUMONT, Louis. O individualismo. Uma perspectiva antropológica da ideologia moderna. Rio de Janeiro: Rocco, 1985.

DURAND, Gilbert. A imaginação simbólica. São Paulo: Cultrix, 1988.

ECKERT, C. A cultura do medo e as tensões do viver a cidade: narrativa e trajetória de velhos moradores de Porto Alegre. Antropologia, saúde e envelhecimento. Rio de Janeiro: Editora Fiocruz, 2002. p. 73102.

ECKERT, C.; ROCHA, A. L. A vocação do etnógrafo na cidade. Revista Brasileira de Sociologia da Emoção, UFPB, 2004.

ECKERT, Cornelia. Questões em torno do uso de relatos e narrativas biográficas na experiência etnográfica. Humanas, RIFCH/UFRGS, vol.1, n. 19/ 20, Porto Alegre, 1996-1997.

ELIAS, Norbert. A sociedade dos indivíduos. Rio de Janeiro: Jorge Zahar Editor, 1994.

FERREIRA, Jonatas. Da vida ao tempo: Simmel e a construção da subjetividade no mundo moderno. $R B C S$, vol. 15, n. 44, outubro/2000. p. 103-117.

FOUCAULT, Michel. Microfisica do poder. Rio de Janeiro: Graal, 1979.

Vigiar e punir. Petrópolis: Vozes, 1988.

FREUD, Sigmund. Moral sexual civilizada e doença nervosa moderna. In: FREUD. Livro 31. Rio de Janeiro: Imago, 1986.

FREUND, Julien. De Max Weber à Georg Simmel. Revue Sociétés, n. 37, Ed. Dunod, 1992. p. 217-224.

GEERTZ, Clifford. A interpretação das culturas. Rio de Janeiro: Zahar, 1978.

GIDDENS, Anthony. A constituição da sociedade. São Paulo: Martins Fontes, 1989.

As conseqüências da modernidade. São Paulo: Unesp, 1991.

GOFFMAN, E. La mise en scène de la vie quotidienne. Paris: De Minuit, 1973.

HABERMAS, Jurgen. L'espace public. Paris: Payot, 1978.

HALBWACHS, Maurice. La mémoire colletive. Paris: PUF, 1968.

HARVEY, David. Condição pós-moderna. São Paulo: Loyola, 1996.

JEUDY, H-P. Mémoires du social. Paris: PUF, 1986. $171 \mathrm{p}$. 
LAHIRE, Bernard. Homem plural. Petrópolis: Vozes, 2002.

LASCH, Christopher.The culture of narcisism: american life in the age of diminishing expectations. New York: Mouton, 1978.

LATOUR, Bruno. Jamais fomos modernos. Rio de Janeiro: Editora 34, 1994.

L'ECOLE DE CHICAGO. Naissance de l'écologie urbaine. Paris: Aubier Montaigne, 1984.

LIMENA, Maria Margarida Cavalcanti. Mundo em crise? Revista Margem. Temporalidades. Faculdade de Ciências Sociais - PUC-SP. Educ, 1996. p. 60.

MAFFESOLI, M. Aux creux des apparences. Pour une éthique de l'esthétique. Paris: Plon, 1990. Cap. I e II.

MORAES FILHO, E. Simmel. São Paulo: Editora Ática, 1990.

OLIVEN, Ruben George. Violência e cultura. Petrópolis: Vozes.

RABINOW, Paul. Antropologia da razão. Rio de Janeiro: Relume-Dumará, 2002.

RICOEUR, Paul. O si-mesmo como um outro. São Paulo: Papirus, 1991.

2000.

. La mémoire, l'histoire, l'oubli. Paris: Seuil,

SCHUTZ, Alfred. Estudios sobre teoria social. Buenos Aires: Amorrortu editores, 1972.

SENNETT, Richard. O declínio do homem público As tiranias da intimidade. São Paulo: Companhia das Letras, 1988.

SIMMEL, Jorge. Cultura femenina y otros ensayos. Madrid: Revista de Occidente, 1934.

SIMMEL, Georg. A metrópole e a vida mental. In: VELHO, Otávio G. (Org). O fenômeno urbano. Rio de Janeiro: Zahar, 1979.
SOARES, Luiz Eduardo. Homicídios dolosos praticados contra menores no estado do Rio de Janeiro. Relatório de pesquisa desenvolvido como parte do plano de trabalho do Projeto Se Essa Rua Fosse Minha. (Fase, Ibase, Idac, Iser). Rio de Janeiro, 1991.

Violência e cultura do medo no Rio de Janeiro. Palestra proferida no PPG Antropologia Social UFRGS, março 1995. [Mimeo.]

O rigor da indisciplina. Rio de Janeiro: Relume-Dumará, 1994.

VELHO, Gilberto. O cotidiano da violência: identidade e sobrevivência. Boletim do Museu Nacional. Nova série. Rio de Janeiro, Brasil. Antropologia, n. 56, 30 de abril de 1987.

. A utopia urbana. Rio de Janeiro: Zahar, 1973.

Individualismo e cultura. Notas para uma antropologia da sociedade contemporânea. Rio de Janeiro: Zahar, 1981.

Projeto e metamorfose. Antropologia das sociedades complexas. Rio de Janeiro: Jorge Zahar, 1994.

(Org). O fenômeno urbano. Rio de Janeiro: Zahar, 1979.

WAGNER, Helmut R. (Org.). Fenomenologia e relações sociais. Textos escolhidos de Alfred Schutz. Rio de Janeiro: Zahar, 1979.

WAIZBORT, Leopoldo. As aventuras de Georg Simmel. São Paulo: Editora 34, 2000.

ZALUAR, Alba. A máquina e a revolta. São Paulo: Brasiliense, 1985.

Condomínio do diabo. Rio de Janeiro: Revan e UFRJ, 1994.

. Medo do crime, medo do diabo. Campinas/ Rio de Janeiro: Unicamp/IMS-UERJ, 1994. 